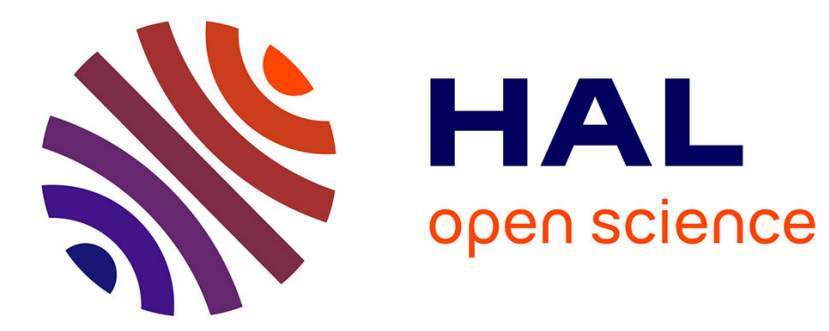

\title{
Green Virtual Enterprise Broker: Enabling Build-to-Order Supply Chains for Sustainable Customer-Driven Small Series Production
}

David Romero, Sergio Cavalieri, Barbara Resta

\section{- To cite this version:}

David Romero, Sergio Cavalieri, Barbara Resta. Green Virtual Enterprise Broker: Enabling Build-toOrder Supply Chains for Sustainable Customer-Driven Small Series Production. IFIP International Conference on Advances in Production Management Systems (APMS), Sep 2014, Ajaccio, France. pp.431-441, 10.1007/978-3-662-44736-9_53 . hal-01387912

\section{HAL Id: hal-01387912 \\ https://hal.inria.fr/hal-01387912}

Submitted on 26 Oct 2016

HAL is a multi-disciplinary open access archive for the deposit and dissemination of scientific research documents, whether they are published or not. The documents may come from teaching and research institutions in France or abroad, or from public or private research centers.
L'archive ouverte pluridisciplinaire $\mathbf{H A L}$, est destinée au dépôt et à la diffusion de documents scientifiques de niveau recherche, publiés ou non, émanant des établissements d'enseignement et de recherche français ou étrangers, des laboratoires publics ou privés. 


\title{
Green Virtual Enterprise Broker: Enabling Build-to-Order Supply Chains for Sustainable Customer-Driven Small Series Production
}

\author{
David Romero $^{1-2}$, Sergio Cavalieri ${ }^{3}$, Barbara Resta ${ }^{3}$ \\ ${ }^{1}$ Tecnológico de Monterrey, Mexico, ${ }^{2}$ Griffith University, Australia \\ david.romero.diaz@gmail.com \\ ${ }^{3}$ University of Bergamo, Department of Engineering \\ CELS - Research Group on Industrial Engineering, Logistics and Service Operations \\ sergio.cavalieri@unibg.it, barbara.restalunibg.it
}

\begin{abstract}
Global businesses are moving towards 'glocalization' and 'masscustomization' strategies to serve in a more personal and sustainable way their customers. Advances in ICT and green manufacturing technologies are enablers of this phenomenon. This paper explores a new business model, and its related supply chain model, the Green Virtual Enterprise Broker, which is fully customer-driven and aware of the environmental footprint of products and services to serve customized and small series production demands.
\end{abstract}

Keywords: Glocalization, Mass-Customization, Sustainability, Build-to-Order Supply Chains, Small Series Productions, Green Virtual Enterprise, Brokerage.

\section{Introduction}

To satisfy the consumers' desire for personalized products, many manufacturing enterprises have nowadays diversified their product lines to appease every consumer taste. Nevertheless, this approach to product diversification has backfired, resulting in failed product launches, huge overstock and significant upfront costs, since a greater variety of product options usually leads to more dissatisfied consumers, due to raised expectations and unattainable perfection [1]. This reality has left many manufacturing enterprises with negative economic, social and environmental footprints that can be translated into capital losses on new product development investments, unsatisfied consumers in target customer segments, and wasted resources related to unsold products [2]. As a result, new business models, and their related supply chains, are required to support in a sustainable way the emerging consumer trends of mass-customization (small series production) and personalization (single product) to individual customers or communities [3], relying on novel production paradigms characterized by flexible open manufacturing networks of small production units. Furthermore, Internet sales, both B2C \& B2B, have made any product globally accessible for purchase, but its delivery and provisioning of life cycle services is a different challenge for traditional business solutions. In this sense, the notion of a Glocal Networked Enterprise presents a promising hybrid agile and lean supply chain and business model that can effectively and efficiently support highly customized and service-enhanced products along their lifecycle by involving manufacturers, customers, communities, third-party logistics providers and local service suppliers in a business ecosystem.

This paper explores a new business model, and its related supply chain model, the Green Virtual Enterprise Broker, which is fully customer-driven and aware of the environmental footprint of products and services along their lifecycle.

\section{Sustainable Customer-Driven Business Models}

New sustainable and customer-driven business models will continue emerging in the coming years due to the rapid advances in information and communication technologies, as well as in green manufacturing technologies, that have the potential to support a new generation of supply chain models. Such models will be characterized by the customer involvement in the supply chain as co-inventors (e.g. Quirky), codesigners (e.g. mi Adidas), or even as part of the assembly and delivery activities (e.g. IKEA); retailers as virtual business brokers; independent manufacturers as product development networks; and independent suppliers as logistics and product servicing

adfa, p. 1, 2011.

(C) Springer-Verlag Berlin Heidelberg 2011 
networks. As a result, future business scenarios are based on collaborative and participatory business models and networked enterprises [2].

\subsection{Sustainable Business Models}

Sustainable business models seek to go beyond delivering economic value - in accordance with a triple bottom line approach. According to Lüdeke-Freund [4] a sustainable business model seeks to create balanced social, environmental and economic value through integrating sustainability more fully into its business model and value proposition(s). Furthermore, Short et al. [5], define a sustainable value proposition as a long-term shareholder value created as a scalable source of competitive advantage by embracing opportunities and managing the risks/benefits associated with their economic, environmental and social developments.

Moreover, Stubbs and Cocklin [6] state that sustainable business models use both a system and firm-level perspective, built on the triple bottom line approach, to define a supply chain model with a wider range of stakeholders. Sustainable business models require collaboration between companies, governments, communities and households; people and their communities play a critical role to bring such a change if provided with the smart thinking to increase efficiency and improve the usage of environmental resources, waste reduction and communal use of products or services (where possible) [7]. As a result, next generation supply chain models will be based on sustainable business models capturing economic value, while protecting the environmental and generating social value for the customer by improving his/her quality of life through highly customized value propositions.

\subsection{Customer-Driven and Community-Driven Business Models}

Customer preferences are an important element in any business model and supply chain, since economic value is captured from customers [8]. Customer value refers to what the customer wants with certain limitations related to his/her purchasing power [9]. Therefore, in this context a customer-driven business model can be defined as a business model that echoes the voice of the customer and aims to meet or exceed his/her personal preferences based on main basic judging elements, such as: product functional features, service mix and quality, total cost of ownership, social and environmental impact.

Such customer-driven viewpoint, which can be seen as an on-demand manufacturing approach, can offer customers the opportunity for customizing or personalizing their products and manufacturing enterprises to increase their manufacturing resources productivity by avoiding unsold products.

In addition, to create new sources of value, several industrial sectors are striving to provide integrated product-service solutions, breaking down the traditional barriers between products and services. Product-Service Systems (PSS) prevail as a systemic approach for enabling a strategic and managerial transition from selling the pure artefacts to deliver a customized and result-oriented solution providing a unique and positive experience to the user throughout his/her journey with the adopted solution [10].

With result-oriented solutions customers get the ownership benefits with less personal burden, cost savings and lower impact on environment, hence showing more captivating alternative to standard and traditional buying and ownership styles. The focus is not limited to the communal use of products and services, but the primary objective is to promote and encourage the active role of consumers towards sustainable communities. Collaborative lifestyles are ideas based on people with similar interests coming together to share and exchange less tangible assets such as time, space, skills and money. As a result, customer-driven models are escalating towards community-driven models, considering that the choices of the single customers are not taken on an individual base but rather with their explicit awareness of the benefits or the rebound effects that their decisions could exert on the community they belong to. Collaborative business models like: sharing, lending, exchange, swapping, and bartering are now able to operate again on a large scale, across geographic boundaries, thanks to the advent of modern technology [11]. 


\section{Production Challenges in Small Series Productions}

Capturing sustainable value in small series productions and/or personalized products in a global marketplace requires the interplay of various collaborative networks (e.g. a business ecosystem), such as product development and servicing networks, including customers and local stakeholders, co-creating highly customized and serviceenhanced products [12] [13].

In the following sections, different production approaches will be explored to offer highly customized products to single customers or community of customers in a sustainable way.

\subsection{Small Series Production (Special Edition Items)}

A Small Series Production (SSP) is characterized by a small run (small lot size) and a low number of repetitions (frequency a product run is repeated) [14]. From a marketing perspective, a small series production is known as a special edition, and represents a restricted number of products being produced every once in a while (e.g. season) with some extra materials of some kind included and/or certain level of customization. For example: textiles, clothing and footwear seasons collections. Small series productions, or special editions, call for a Configure-to-Order (CTO) production approach offering customers a standard customization based on a predefined number of customization alternatives (e.g. a solution space ${ }^{1}$ ) aiming to satisfy their demand. Special editions are customized based on standard product designs, have a slightly higher cost, a limit variety, and are produced only when an order is placed.

Table 1 presents some of the production and supply chain management (SCM) characteristics and challenges of a CTO operational model to support global small series productions.

Table 1 - Production \& Supply Chain Management Challenges in SSPs

\begin{tabular}{|l|l|l|}
\hline Process & Characteristics & Challenges \\
\hline \multirow{2}{*}{ Design \& Engineering } & $\begin{array}{l}\text { - Standard customization. } \\
\text { - Medium customer-driven design. }\end{array}$ & $\begin{array}{l}\text { - Designs based on common parts } \\
\text { and modular subassemblies. }\end{array}$ \\
\hline \multirow{3}{*}{ Production } & $\begin{array}{l}\text { - Pull order system. } \\
\text { - Medium volume. }\end{array}$ & $\begin{array}{l}\text { Inventory management across } \\
\text { the supply chain. }\end{array}$ \\
& $\begin{array}{l}\text { - Medium flexibility. } \\
\text { - Medium to Short cycle time. }\end{array}$ & \\
\hline Logistics \& Distribution & $\begin{array}{l}\text { - Medium inventory costs. } \\
\text { - Medium total costs. }\end{array}$ & $\begin{array}{l}\text { - High supply chain management } \\
\text { and integration. }\end{array}$ \\
\hline
\end{tabular}

\subsection{One-Time Production (Limited Edition Items)}

A One-Time Production (OTP) is characterized by a small run; i.e. only one small lot is produced and the product is not manufactured again (repetitions $=$ zero) [14]. From a marketing perspective a one-time production is known as a limited edition, and represents a restricted number of products being produced for a unique time with a particular design. For example: exclusive sport and luxury cars production.

On-time productions, or limited editions, call for a Make-to-Order (MTO) production approach offering a high level of customization (one of a kind) and high quality. Limited editions are tailored (an exclusive design), have a high cost, a limit number of units, and are produced only when an order is placed.

Table 2 presents some of the production and SCM characteristics and challenges of a MTO operational model to support global on-time productions.

\subsection{Personalized Production (Deluxe Item)}

A Personalized Production $(P P)$ is characterized by a one item production according to single customer requirements [14]. From a marketing perspective, a personalized production is known as a deluxe item, and represents a unique engineering design or

\footnotetext{
${ }^{1}$ A solution space encompasses all the possible designs a toolkit can produce.

${ }^{2}$ A focal enterprise "is the initiator of an international business transaction, including multinational and small/medium size enterprises, that conceives, designs, and produce
} 
significant customization according to be produced according to specific customer's requirements. For example: a personalized competition sportswear or equipment for a professional athlete.

Table 2 - Production \& Supply Chain Management Challenges in OTPs

\begin{tabular}{|l|l|l|}
\hline Process & Advantages & Challenges \\
\hline \multirow{3}{*}{ Design \& Engineering } & - One of a kind customization. & - Low standard parts ratio. \\
& - Tailored customization. & - Customization extent is high. \\
& - None customer-driven design. & \\
\hline \multirow{3}{*}{ Production } & - Pull order system. & - Demand quantity is small. \\
& - Medium to low volume. & - Production planning based on \\
& - Medium flexibility. & order. \\
& - Medium cycle time. & - by customer orders. \\
& - Low inventory costs. & - Medium delivery time. \\
\hline Logistics \& Distribution & - Medium total costs. & - None supply chain integration. \\
\hline
\end{tabular}

Personalized productions, or deluxe items, call for an Engineer-to-Order (ETO) production approach offering a complete involvement of the customer in the item (product) design and engineering (e.g. unique design, set of part numbers, bill of materials, routing, etc.). Deluxe items are developed from scratch for each single customer, and therefore have a high cost and are produced only when an order is placed.

Table 3 presents some of the production and SCM advantages and challenges of an ETO operational model to support global personalized productions.

Table 3 - Production \& Supply Chain Management Challenges in PPs

\begin{tabular}{|c|c|c|}
\hline Process & Advantages & Challenges \\
\hline Design \& Engineering & $\begin{array}{l}\text { - High customization } \\
\text { (personalization). } \\
\text { - High customer-driven design } \\
\text { (full involvement). }\end{array}$ & - High product complexity. \\
\hline Production & $\begin{array}{l}\text { - Pull order system. } \\
\text { - Low volume. } \\
\text { - High flexibility. } \\
\text { - Large cycle time. } \\
\text { - None inventory costs. } \\
\text { - High total costs. }\end{array}$ & - Long delivery time. \\
\hline Logistics \& Distribution & - Large cycle time. & - Long delivery time. \\
\hline
\end{tabular}

\subsection{Collective Production (Shared Item)}

A Collective Production ( $C P$ ) is characterized by the production of a bundle of products and services according to the requirements of a close community of customers. From a marketing perspective, a collective production could be termed as shared item, since design, engineering and delivery requires a significant customization according to the specific local and cultural needs of the community sharing the common solution. For example: energy management systems, local mobility systems, healthcare systems.

This kind of solutions call for a novel Participatory-Engineering-to-Order (P-ETO) production approach, since the whole community, through a participatory mechanism, needs to be involved in the definition of the requirements and the engineering of the shared solution. A top-down approach (without the involvement of the community since the beginning) would inhibit its widespread adoption.

Table 4 - Production \& Supply Chain Management Challenges in CPs

\begin{tabular}{|l|l|l|}
\hline Process & Advantages & Challenges \\
\hline \multirow{3}{*}{ Design \& Engineering } & $\begin{array}{l}\text { - High customization } \\
\text { (personalization). } \\
\text { - High customer-driven design (full } \\
\text { involvement). }\end{array}$ & $\begin{array}{l}\text { - Long design and engineering } \\
\text { time. }\end{array}$ \\
\hline \multirow{3}{*}{ Production } & $\begin{array}{l}\text { - Pull order system. } \\
\text { - Very low volume. }\end{array}$ & $\bullet$ One-of-a-kind supply chain. \\
& $\begin{array}{l}\text { - High flexibility. } \\
\text { - Large cycle time. }\end{array}$ & \\
\hline Logistics \& Distribution & $\begin{array}{l}\text { None inventory costs. } \\
\text { - High total costs. }\end{array}$ & \\
\hline
\end{tabular}


Some of the related challenges that can be foreseen are: (a) engineering and delivering community-driven solutions requires a variety of professional skills, including among others sociologists and urban planners; and (b) given the complexity and the local features of the solution, deriving from an integration of more products and services, the configuration of the supply chain would be one-of-a-kind, specifically designed and scarcely repetitive.

Table 4 presents some of the production and SCM advantages and challenges of a $P$-ETO operational model to support global personalized productions.

\section{Green Virtual Enterprise Broker/Brokerage and their Glocal Networked Enterprises}

Global businesses are moving towards glocalization (globalized but localized) [15] and mass-customization strategies to serve in a more personal and sustainable way their customers [16]. Authors define a Green Virtual Enterprise Broker (GVE-Broker) as a new business model where a focal enterprise ${ }^{2}$ creates sustainable value by mobilizing and managing processes and resources rather than owning them. A GVEBroker business model relies on a Glocal Networked Enterprise (GNE) composed by a network of enterprises, with global presence as network, but with locally available skills or core-competences and resources at the localities of their member enterprises to better serve customers worldwide.

A $G N E$ is a breeding environment ${ }^{3}$ for the dynamic creation of Build-to-Order (BTO) supply chains [3], named: virtual manufacturing and/or service enterprises [2], to meet the specific requirements of customers, and at the same time adopt, under case by case bases (the business opportunity characterization) the proper supply chain strategy/model (e.g. agile, lean, flexible) to cope with the uncertainties faced by the demand and sustainable and competitive supply of small series productions and personalized products, and their related services [18]. By associating the right business partners in a Green Virtual Enterprise (VE), BTO supply chains [3] [16] can face the challenges of a customer- or community-driven and sustainable supply chain with global added value product-service systems as customized 'value propositions'; at the same time they would achieve a sustainable competitive advantage through the efficient use of locally available resources and competences in glocal networked member enterprises to reduce costs, lead time, environmental footprint and social negative impacts.

GVE-Brokers activities will be performed by means of a web-based collaborative solution platform (e.g. an e-marketplace) for the realization of sustainable business ecosystems for the co-creation, manufacturing and delivery of customized productservices in distributed markets.

This web-based collaboration solution platform (see Table 5) will have a threefold service support offer for: (a) services for customers based on user toolkits ${ }^{4}$ for masscustomization, personalization and participatory engineering of value propositions, where customers can access to a solution space for co-innovating, co-creating and/or co-developing his/her own products and services [19] [20] [21] [22], (b) services for GVE-brokers based on GVE creation tools named: opportunity identification and characterization, GVE rough planning, GVE partners search and suggestion, GVE composition, GVE partners negotiation, detailed GVE planning, GVE partners contracting, and GVE set-up [23] [24] [25], and (c) services for GVE coordinators based on GVE management tools such as: project planning and decision support, project execution and monitoring, and customer follow-up [23] [26].

User toolkits as virtual tools build an interface between manufacturers and service providers and their customers. User toolkits can be employed by manufacturers and

\footnotetext{
${ }^{2}$ A focal enterprise "is the initiator of an international business transaction, including multinational and small/medium size enterprises, that conceives, designs, and produce the offerings (goods and services) intended for consumption by customers worldwide" [17].

${ }^{3}$ A virtual enterprise breeding environment is a long-term strategic alliance of enterprises aimed at offering the necessary conditions to support the rapid and fluid configuration of virtual manufacturing and/or service enterprises [2].

${ }^{4} \mathrm{~A}$ user toolkit is a technology that allows users to design a novel product via trial-and-error experimentation and deliver them an immediate (simulated) feedback on the potential outcome of their design ideas [19].
} 
service providers to get an exact purchase order and therefore produce customized products just when the customers need them and only in the quantity they are needed. Hence, user toolkits offer two advantages: (a) allow users to exactly specify their design preferences reducing the possibility of unsold products and increasing customer satisfaction, and (b) improve customer relationship [19] [20] [21] [22].

Table 5 - The Green Virtual Enterprise Broker and its Solution Platform Overview

\begin{tabular}{|c|c|c|c|}
\hline Building Blocks & \multicolumn{3}{|l|}{ Types } \\
\hline Value Proposition(s) & \multicolumn{3}{|c|}{ - Mass-customized $\bullet$ Personalized $\bullet$ Shared } \\
\hline Customer Segments & \multicolumn{3}{|c|}{ - Individual customers $\bullet$ Customer niche $\bullet$ Customer community } \\
\hline Customer Relationships & \multicolumn{3}{|c|}{ - Customer-driven (co-innovation, co-creation, co-development) } \\
\hline Channels & \multicolumn{3}{|l|}{ - e-Marketplace } \\
\hline $\begin{array}{l}\text { Key Partners } \\
\text { (stakeholders) }\end{array}$ & \multicolumn{3}{|c|}{$\begin{array}{c}\text { Glocal Networked Enterprise: } \\
\bullet \text { Manufacturers } \bullet \text { Service Providers } \bullet \text { Customers \& Communities } \bullet \text { Brokers }\end{array}$} \\
\hline \multirow{3}{*}{$\begin{array}{l}\text { Key Activities \& } \\
\text { Resources }\end{array}$} & Front-end & Intermediary & Back-end \\
\hline & $\begin{array}{l}\text { User toolkits for: } \\
\text { mas-customization, } \\
\text { personalization and } \\
\text { participatory } \\
\text { engineering }\end{array}$ & $\begin{array}{l}\text { Broker toolkit for: } \\
\text { - Opportunity } \\
\text { characterization } \\
\text { - Partners search and } \\
\text { selection } \\
\text { - Topology set-up } \\
\text { - Schedule activities } \\
\text { - Assign tasks } \\
\text { - Allocate budget } \\
\text { - Define KPIs } \\
\text { - Identify risks }\end{array}$ & $\begin{array}{l}\text { Networked Enterprise } \\
\text { toolkit for: } \\
\text { - Monitor activities } \\
\text { - Monitor finance } \\
\text { - Monitor KPIs } \\
\text { - Measure indicators } \\
\text { - Manage exceptions } \\
\text { - Monitor risks } \\
\text { - Liability (guarantees) }\end{array}$ \\
\hline & \multicolumn{3}{|c|}{$\begin{array}{c}\text { e-Marketplace Platform: An interactive environment for } \\
\text { value co-creation and collaborative supply chain management. }\end{array}$} \\
\hline Cost Structure & \multicolumn{3}{|c|}{ - Costing models (e.g. variables costs + economies of scope). } \\
\hline Revenue Streams & \multicolumn{3}{|c|}{ - Profit models (e.g. subscription fees + brokerage fees). } \\
\hline
\end{tabular}

GVE creation tools will support GVE-brokers to find glocally (globally and locally) the right GVE partners considering the availability of their green capabilities and capacities, cost, and localization in order to build the best supply chain possible with the shortest lead time, cost and environmental footprint. Within the GVE creation tools, those related to GVE partners search and suggestion will play a vital role to help GVE-brokers to find and evaluate different feasible GVE configurations with respect to customer-, economic-, social- and environmental- oriented criteria (e.g. customer preferences, production cost, delivery cost, lead time, footprint, green technologies, etc.) [23] [24] [25].

Thus, GVE-brokers capability to dynamically create BTO supply chains, tailored within a glocal networked enterprise, seems to be the most promising sustainable strategy to support 'glocal markets' and respond to the quality-, time-, cost- and environmental- frames demanded by the consumers of customized and small series production products that want a premium customer service (attention) and the feel of proximity (near-by store) when it comes to the services associated to their products. In this scenario (see Fig. 1), glocal networked enterprises are an encouraging organizational model to enable agile, lean, and reasonably priced production and services activities glocally-wide [27].

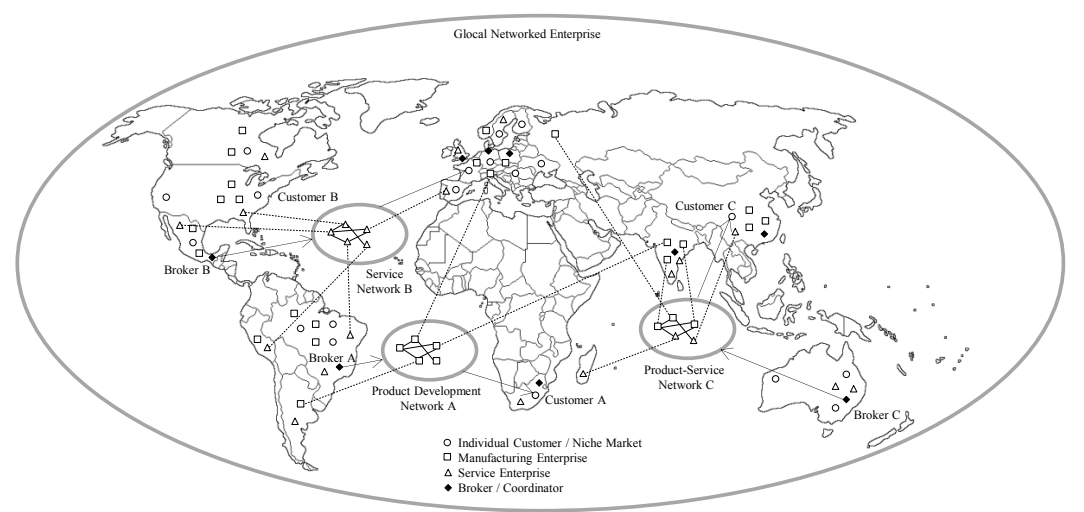

Fig. 1. Glocal Networked Enterprise World-Wide Operations

GVE management tools will support GVE coordinators in their main activity of orchestrating the glocal networked enterprise's product development and servicing 
networks to strengthen a structure for 'glocal operations ${ }^{5}$ that responds to individual and niche customers' needs on a global scale with the shortest lead time, cost and environmental footprint possible [23] [26]. GVE coordinators will formulate 'glocal strategies' to incorporate the adaptation of the network glocal core-competences and resources, business opportunities characteristics, and location of the glocal networked member enterprises to suit the requirements of a local customer and attain a new competitive advantage. GVE coordinators will utilize the glocal network experience for customizing products and services in such way that appeal to local/niche markets (small series productions) and single customers (personalization) [28] [29] [30].

\section{Conclusions and Future Work}

Glocal Networked Enterprises are becoming a needed reality in a globalized marketplace (e.g. e-commerce), aided by an emerging consumer trend for customized products, and supported by the progress in information, communication and production technologies (e.g. Big Data, Internet of Things, 3D printing). Furthermore, future glocal networked solutions will have to face the constraints to achieve an economically, socially and environmentally sustainable industrial landscape and marketplace in a global perspective [18].

Green Virtual Enterprise Brokers and their Glocal Networked Enterprises offer an encouraging organizational model for managing 'glocal operations' by means of the cooperation of manufacturing and service enterprises to fulfill world-wide various production and service provision needs. Hence, new markets are opening up for customized and small series production products and their related services but require new collaborative supply chain and business models [30].

Further work is needed to develop not only new collaborative supply chain and business models but also new methods and (ICT) tools to enable 'BTO supply chains for sustainable customer-driven small series productions'.

\section{References}

1. Markwart, A.: Emerging Consumer Trends - Customization, (2013), URL: http://www.vancitybuzz.com/2013/11/emerging-consumer-trends-customization/

2. Romero, D., Molina, A.: Forward - Green Virtual Enterprises and their Breeding Environments: Sustainable Manufacturing, Logistics \& Consumption. To appear in PROVE 2014 Conference Proceedings.

3. Molina, A., Velandia, M., Galeano, N.: Virtual Enterprise Brokerage: A Structure-Driven Strategy to Achieve Build to Order Supply Chains. International Journal of Production Research 45(17), pp. 3853-3880 (2007)

4. Lüdeke-Freund, F.: Towards a Conceptual Framework of Business Models for Sustainability. Knowledge Collaboration \& Learning for Sustainable Innovation, Delft, The Netherlands (2010)

5. Short, S.W., Bocken, N.M.P., Rana, P., Evans, S.: Business Model Innovation for Embedding Sustainability - A Practice-Based Approach Introducing Business Model Archetypes. 10th Global Conference on Sustainable Manufacturing (2012)

6. Stubbs, W., Cocklin, C.: Conceptualizing a "Sustainability Business Model". Organization \& Environment, 21(2), pp. 103-127 (2008)

7. Bartolomeo, M. et al.: Eco-Efficient Services - What are they, How do they Benefit Customers and the Environment and How likely are they to Develop and be Extensively Utilized, Journal of Cleaner Production, 11(8), pp. 829-837 (2003)

8. Bowman, C., Ambrosini, V.: Value Creation versus Value Capture: Towards a Coherent Definition of Value in Strategy. British Journal of Management, 11, pp. 1-15 (2000)

9. Pynnönen, M.: Customer Driven Business Model - Connecting Customer Value to Firm Resources in ICT Value Networks. PhD Thesis, Universitatis Lappeenrantaensis (2008)

10. Cavalieri, S.; Pezzotta, G.: Product-Service Systems Engineering: State of the Art and Research Challenges. Computers in Industry, 63(4), pp. 278-288, (2012)

11. Botsman, R., Roger, R.: What's Mine Is Yours: The Rise of Collaborative Consumption. HarperBusiness (2010)

12. Camarinha-Matos, L.M., Macedo, P., Ferreda, F., Oliveira, A.I.: Collaborative Business Scenarios in a Service-enhanced Products Ecosystem, In: L.M. Camarinha-Matos et al. (Eds.): PRO-VE 2012, IFIP AICT 380, pp. 13-25 (2012)

\footnotetext{
${ }^{5}$ Glocal operations can be defined as strategies for providing a global offer while taking local related issues into account and therefore meeting certain local/particular needs or preferences, at lower costs due to the global edge of the networked enterprise [30].
} 
13. Camarinha-Matos, L., Ferreda, F., Oliveira, A.I.: Interplay of Collaborative Networks in Product Servicing. , In: L.M. Camarinha-Matos \& R.J. Scherer (Eds.): PRO-VE 2013, IFIP AICT 408, pp. 53-62 (2013)

14. Lödding, H.: Handbook of Manufacturing Control: Fundamentals, Description, Configuration, Springer, pp. 101-103 (2013)

15. Hesselbach, J., Herrmann, C.: Glocalized Solutions for Sustainability in Manufacturing Preface. Springer-Verlag (2011)

16. Romero, D., Molina, A.: Collaborative Networked Organisations and Customer Communities: Value Co-creation and Co-innovation in the Networking Era. Journal of Production Planning \& Control, 22(5-6), pp. 447-472 (2011)

17. Cavusgil, T.S., Knight, G., Riesenberger, J.R.: International Business Strategy, Management and New Realities, Pearsons Prentice Hall, USA (2008)

18. Hau, L.: Aligning Supply Chain Strategies with Product Uncertainties. California Management Review, 44(3), pp. 105-119 (2002) Hesselbach, J., Herrmann, C.: Glocalized Solutions for Sustainability in Manufacturing - Preface. Springer-Verlag (2011)

19. von Hippel, E.: Perspectives: User Toolkits for Innovation. Journal of Product Innovation Management, 18(4), pp. 247-257 (2001)

20. von Hippel, E., Katz, R.: Shifting Innovation to Users via Toolkits. Management Science, 48 (7), pp 821-833 (2002)

21. Franke, N., Piller, F.: Key Research Issues in User Interaction with User Toolkits in a Mass Customisation System. International Journal of Technology Management 26(5), pp. 578-599 (2003).

22. Hermans, G.: A Model for Evaluating the Solution Space of Mass Customization Toolkits. International Journal of Industrial Engineering and Management, 3(4), pp. 205-214 (2012)

23. Romero, D., Molina, A.: Green Virtual Enterprises Breeding Environment Reference Framework. In: L.M. Camarinha-Matos et al. (Eds.), PRO-VE 2011, IFIP AICT 362, pp. 545-555 (2011)

24. Camarinha-Matos, L.M. et al.: VO Creation Assistance Services. Methods and Tools for Collaborative Networked Organizations, Springer, pp. 155-190 (2008)

25. Wang, X., Wonga, T.N., Wang, G.: An Ontological Intelligent Agent Platform to Establish an Ecological Virtual Enterprise. Expert Systems with Applications, 39, pp. 7050-7061 (2012)

26. Negretto, U. et al.: VO Management Solutions - VO Management e-Services. Methods and Tools for Collaborative Networked Organizations, Springer, pp. 257-274 (2008)

27. Hartel I., Billinger S., Burger G., Kamio, Y.: Virtual Organization of After-Sales Service in the One-of-a-Kind Industry. In: L.M. Camarinha-Matos et al. (Eds.), Collaborative Business Ecosystems and Virtual Enterprises, Kluwer Academic Publishers, pp. 405-420 (2002)

28. Dumitrescu, L., Vinerean, S.: The Glocal Strategy of Global Brands. Journal Studies in Business and Economics, 5(3), pp. 147-155 (2010)

29. Foglio, A., Stanevicius, V.: Scenario of Glocal Marketing as an Answer to the Market Globalization and Localization. Part I: Strategy Scenario and Market, Vadyba/Managemt, pp. 26-38 (2007)

30. Johanisson, B.: Building a "Glocal" Strategy - Internationalizing Small Firms through Local Networking, 39ème Conférence Mondiale de l'ICSB: "Les PME/PMI et leur contribution au développement régional et international”, pp. 127-135 (1994) 